\title{
PELATIHAN PENGGUNAAN METODE JARIMATIKA UNTUK MENANAMKAN KONSEP CARA MUDAH MENGHITUNG PERKALIAN PADA SISWA SEKOLAH DASAR RW. O1 KELURAHAN KIBING
}

\author{
THE TRAINING USE OF JARIMATIKA METHOD TO INCULCATE THE EASY WAY \\ OF CALCULATING SKILL OF ELEMENTARY SCHOOL STUDENTS IN RW. 01 \\ KIBING AREA
}

\author{
Asmaul Husna \\ Prodi Pendidikan Matematika, Fakultas Keguruan dan Ilmu Pendidikan, \\ Universitas Riau Kepulauan, Batam, Indonesia \\ Asmaul_uul25@yahoo.com
}

\begin{abstract}
Abstrak
Pelaksanaan program pengabdian ini didasarkan pandangan siswa-siswa Sekolah Dasar (SD) di RW.01 Kelurahan kibing terhadap Matematika adalah mata pelajaran yang sulit, sehingga minat siswa terhadap matematika cukup rendah. Terbukti dengan kurangnya kemampuan siswa dalam operasi dasar Aritmatika khususnya perkalian. Tujuan pelaksanaan program ini adalah : (a) meningkatkan pengetahuan dan keterampilan siswa tentang penggunaan metode jarimatika pada operasi dasar aritmatika khususnya perkalian, (b) melatih dan mendampingi siswa tentang penggunaan metode jarimatika. Metode pelaksanaan kegiatan meliputi tiga tahap, yaitu : perencanaan, tindakan dan evaluasi. Hasil pelaksanaan program adalah (a) adanya peningkatan pengetahuan dan keterampilan siswa tentang penggunaan metode jarimatika pada operasi dasar aritmatika khususnya perkalian dalam kategori cukup baik, (b) kemampuan siswa dalam penggunaan metode jarimatika berkualitas baik.
\end{abstract}

Kata Kunci : Metode Pembelajaran, Jarimatika

\begin{abstract}
Implementation of this service program based on the view of elementary school students (SD) in RW.01 kibing area to Mathematics is a difficult subject, so that student interest to math is quite low. Evidenced by the lack of student ability in basic operations of Arithmetic in particular multiplication. The objectives of this program are: (a) to improve the students' knowledge and skills about the use of the jarimatika method on arithmetic base operation, especially multiplication, (b) train and assist students about the use of the jerimatika method. Method of implementation of activities includes three stages, namely: planning, action and evaluation. The results of program implementation are (a) the improvement of students 'knowledge and skills about the use of the jarimatika method of arithmetic in basic arithmetic operations, especially multiplication in good enough category, (b) students' ability in using good quality jarimatika method.
\end{abstract}

Keywords: Learning Method, Jarimatika 


\section{PENDAHULUAN}

Anak-anak di RT.02 dan RT.04 RW.01 kelurahan Kibing, Kecamatan Batu Aji Kota Batam menikmati pendidikan seperti yang seharusnya mulai dari jenjang Taman Kanak-kanak sampai Perguruan Tinggi, Berdasarkan hasil wawancara dengan beberapa anak usia sekolah di RT.04 dan RT.02 diperoleh Informasi yang cukup menarik dari beberapa siswa Sekolah Dasar (SD) di RT.02 dan RT.04 Kelurahan Kibing untuk pembelajaran matematika khususnya pada masalah perkalian siswa sering mengalami kesulitan disaat menyelesaikan tugas yang diberikan oleh guru disekolah yang berhubungan dengan masalah perkalian karena siswa merasa kesulitan untuk mengingat jumlah dalam perkalian yang dalam artian banyak siswa Sekolah Dasar yang tidak hapal perkalian dasar 1 sampai 10. Hal ini disebabkan karena pembelajaran yang dilaksanakan selama ini disekolah sangat jarang menggunakan metodemetode yang inovatif pada khususnya. Siswa belajar matematika lebih banyak melalui penjelasan secara langsung oleh guru yang didominasi dengan pemberian ceramah. Hal ini terjadi sebagai akibat dari pemahaman serta keterampilan guru untuk menggunakan metodemetode inovatif dalam pembelajaran matematika juga kurang. Sebagai akibatnya siswa belajar matematika dengan cara-cara yang kurang bermakna. Siswa cenderung menghafal konsep atau prosedur matematis tertentu. Sehingga mengakibatkan siswa cepat lupa dengan konsepkonsep yang mereka hafal.

Secara umum, proses pembelajaran disekolah berlangsung dengan cukup baik, dengan penggunaan media dan metode pengajaran yang belum optimal. Dan sangat diperlukan variasi media dan metode pembelajaran, sehingga proses belajar mengajar dapat meningkat mutunya. Untuk membantu meningkatkan mutu proses belajar mengajar, khususnya dalam bidang matematika, antara lain dengan memberikan variasi media dan metode pembelajaran. Sehingga minat belajar siswa dapat ditingkatkan, terutama dalam mata pelajaran Matematika yang sering dianggap sulit. Kesan ini dapat dikurangi dengan memberikan variasi media dan model pembelajaran yang dapat menarik minat siswa.

Keberhasilan proses belajar mengajar sangat ditentukan oleh metode pengajaran yang baik, media pembelajaran yang mendukung serta suasana proses belajar yang kondusif. Keterampilan pendidik dalam menumbuhkan motivasi peserta didik juga merupakan salah satu faktor yang mempengaruhi keberhasilan tersebut. 
Penggunaan media pendidikan secara tepat dapat mengatasi sikap pasif peserta didik. Secara rinci media pendidikan berguna untuk :

1. Menimbulkan kegairahan belajar.

2. Memungkinkan interaksi yang lebih langsung antara peserta didik dengan lingkungan dan kenyataan.

3. Memungkinkan peserta didik belajar menurut kemampuan dan minatnya.(Arief, 2000).

Keterampilan untuk mengadakan variasi juga sangat berpengaruh pada keberhasilan belajar peserta didik. Beberapa manfaat memberikan variasi adalah :

1. Menimbulkan dan meningkatkan perhatian peserta didik terhadap proses belajar mengajar.

2. Meningkatkan motivasi dan rasa ingin tahu.

3. Membentuk sikap yang positif.

4. Tercipta suasana nyaman dalam belajar dan terhindar dari kebosanan.(Hendyat,2003). Mempertimbangkan jumlah siswa usia sekolah Dasar di RT.02 dan RT.04 Kelurahan Kibing yang cukup banyak, dengan pemahaman yang masih kurang dalam pembelajaran matematika, khususnya dalam menggunakan metode-metode yang inovatif dalam pembelajaran matematika, maka Dosen bersama dengan dengan mahasiswa sebagai tim pelaksana memandang perlu untuk mengadakan kegiatan pembelajaran tambahan yang menggunakan metode yang inovatif dengan melibatkan para siswa usia sekolah dasar (SD) di daerah ini, hal ini dikarenakan siswa-siswa didaerah ini membutuhkan penyegaran terkait metode pembelajaran yang selama ini cenderung dituntun untuk menghafal. Agar dapat meningkatkan minat mereka dalam pembelajaran khususnya dalam pembelajaran matematika.

Adapun metode pembelajaran yang inovatif yang tim pelaksana berikan pada siswa sekolah dasar di RT.02 dan RT.04 Kelurahan Kibing adalah metode jarimatika. Jarimatika adalah gabungan dari "jari" dan "aritmatika" yang diartikan sebagai cara atau proses hitung dengan menggunakan jari sebagai alat bantu mengoperasikan operasi hitung (Prasetyono, 2009 : 28). Dibandingkan dengan metode lain jarimatika lebih menekankan pada penguasaan konsep terlebih dahulu kemudian cara cepatnya.sehingga anak-anak menguasai ilmu secara matang. 
Metode berhitung dengan jarimatika adalah metode pembelajaran alternatif untuk mengajarkan materi penjumlahan dan pengurangan dan perkalian untuk anak-anak sekolah dasar. Diharapkan dengan metode ini, anak-anak menyukai pelajaran tentang operasi dasar aritmatika khususnya perkalian, dengan cara belajar sambil bermain. Sosialisasi metode ini diperlukan untuk memberikan metode alternatif bagi siswa-siswa sekolah dasar, sehingga pelajaran matematika dapat diajarkan dengan cara yang lebih menarik dan menyenangkan. Sehingga dapat meningkatkan hasil belajar siswa menjadi lebih baik.

Metode jarimatika ini tidak menghilangkan konsep operasi matematis, tetapi proses berhitung dapat diupayakan lebih mudah dan cepat. Metode ini mungkin bersifat primitif, akan tetapi metode ini juga cukup menarik, praktis, sederhana dan ekonomis. Karena hanya menggunakan sepuluh jari tangan kita.

\section{METODOLOGI}

Program ini dilaksanakan dalam tiga tahap, perencanaan, pelaksanaan dan evaluasi (Parwati dan Ariawan, 2013) . kegiatan-kegiatan dalam tahap-tahapan sebagai berikut:

\section{Perencanaan}

Pada kegiatan perencanaan tim pelaksana mengundang mitra untuk dijelaskan maksud, tujuan dan teknis pelaksanaan kegiatan pelatihan, sosialisasi program pada mitra , dan penyusunan program pelatihan.

\section{Tindakan}

Tindakan dalam kegiatan ini berupa implementasi program. Kegiatan-kegiatan yang dilakukan adalah (a) meningkatkan pengetahuan dan keterampilan siswa tentang penggunaan metode jarimatika pada operasi dasar aritmatika khususnya perkalian, (b) melatih siswa tentang penggunaan metode jarimatika, (c) melatih dan mendampingi siswa tentang penggunaan metode jarimatika.

\section{Evaluasi}

Evaluasi dalam kegiatan ini diperlukan untuk mengetahui sejauh mana pemberian metode yang dilakukan tim pelaksana dipahami dan bisa diaplikasikan langsung oleh siswa. Contoh untuk pelatihan penggunaan metode jarimatika tim mengevaluasi dengan cara memberikan beberapa soal yang berhubungan dengan perkalian dan diminta diselesaikan 
secara langsung dengan metode jarimatika, disana akan terlihat sejauh mana metode ini akan membantu siswa dalam meningkatkan hasil belajarnya.

\section{PEMBAHASAN}

\section{Hasil pelaksanaan kegiatan pelatihan}

a. Kegiatan pelatihan penggunaan metode jarimatika dilaksanakan pada hari Minggu, tanggal 20 dan 27 Agustus 2017. Kegiatan pengabdian dihadiri oleh 23 orang peserta dan peserta menunjukkan antusiasme cukup besar terhadap program pengabdian.

b. Materi pelatihan dapat semuanya disampaikan oleh tim pelaksana.

c. Peningkatan Kemampuan peserta pelatihan dalam penguasaan materi dalam kategori cukup baik.

d. Program pelatihan berhasil memberikan penyegaran kepada siswa Sekolah Dasar (SD) dalam perhitungan perkalian tidak harus menghafal lagi.

\section{Pembahasan Hasil Pelaksanaan Kegiatan}

Berdasarkan hasil kegiatan yang telah dipaparkan pada hasil, bahwa kegiatan pengabdian ini mendapat respon yang positif dari siswa-siswa Sekolah Dasar (SD) di RW.01 Kelurahan Kibing, dimana para peserta antusias mengikuti kegiatan, para siswa mengikuti dengan penuh semangat sehingga ketika mereka disuruh untuk mengerjakan latihan yang diberikan para siswa bisa menyelesaikannya dengan baik dan juga mereka dengan senang hati membantu dalam proses awal sampai akhir.

Disisi lain masih ditemukan beberapa kendala dalam pelaksanaan, misalnya menentukan waktu, karna pelatihan ini dijadwalkan hari minggu kebetulan berbarengan dengan perayaan 17 Agustus dan kegiatan-kegiatan lain yang diselenggarakan pada minggu.

\section{KESIMPULAN}

Berdasarkan uraian pada hasil dan pembahasan di atas, maka dapat disimpulkan sebagai berikut:

1. Pelaksanaan kegiatan pelatihan penggunaan metode jarimatika untuk menanamkan konsep cara mudah menghitung perkalian berjalan dengan baik. 
2. Tanggapan mitra terhadap pelaksanaan kegiatan pelatihan cukup baik. Hal ini dapat dilihat dari indikator kehadiran siswa, dan selama kegiatan berlangsung mereka sangat antusias mengikuti kegiatan dari awal sampai akhir kegitan.

\section{REFERENSI}

Arief. S Sadiman, 2005, Media Pendidikan, Pengertian, Pengembangan dan Pemanfaatannya, Pt. Rajagrafindo Persada

Hendyat Soetopo, 2002, Pendidikan dan Pembelajaran : Teori, Masalah dan Praktek, UMM Press

Indarti. 2008. Teknik Berhitung Dengan Menggunakan Jarimatika Guna Mendukung Kecerdasan anak. Jakarta: Bina Sarana Informatika (Jurnal)

LPPM, 2017.Panduan Pengabdian Pada Masyarakat. Lembaga Penelitian dan Pengabdian pada Masyarakat (LPPM), Batam Universitas Riau Kepulauan,

Parwati, Ni Nyoman dan Ariawan, I Putu Wisna.2013. IbM Media Pembelajaran Matematika $S D$. Universitas Pendidikan Ganesha 